6386

Research Article

Journal of Extension Education

Vol. 31 No. 4, 2019

DOI:https://doi.org/10.26725/JEE.2019.4.31.6386-6390

\title{
Perception on the Effectiveness of School Vegetable Garden Programme
}

\author{
T.G. Ajit ${ }^{1}$ and M.J. Mercykutty ${ }^{2}$
}

\begin{abstract}
School vegetable garden is the practice of cultivation of vegetables in and around the school premises by the students. Schoolvegetable garden programme is a promising tool that can teach cultivation of vegetable within the formal educational framework. It provides opportunities for young minds to understand the basic lessons of agriculture and develop an affinity towards it. A study was conducted among 180 student respondents among six schools by adopting the procedure of two stage random sampling, in Nenmara and Kollengode blocks of Palakkad district in Kerala. All the selected schools had functional school vegetable gardens and were practicing activities either through agriculture or nature clubs. The perceived effectiveness of school vegetable garden by students revealed that development of life skills was found to be the most important outcome. The constraints faced by students were more time spent for garden activities and difficulty in maintaining the garden during vacation.
\end{abstract}

Keywords: School vegetable garden; Effectiveness; Perception; Constraint; Kerala.

\section{INTRODUCTION}

The future of Indian agriculture is in the hands of today's growing minds. The present Indian condition is children are far away from agriculture, many children might not be able to recognize the rice plant, the staple food of India. The role of agriculture is greater in the present economy so that the growing generation need to mould according to the present situation. Nowadays the majority of the aspirants focusing on non-agricultural careers, but according to Indian economy agriculture are the backbone, for strengthening it in effective manner educational institutional gardens can play a vital role.

In a focused future development, educational institutional gardens can contribute highly agricultural oriented citizens. In Kerala, the school vegetable garden programmes are implemented by State Agriculture and Farmers Welfare Department as a component of vegetable development programme. The programme aims to mobilize the student community into the field of agriculture, make them aware of safe to eat food production and to bring uncultivable

1 PG Scholar and ${ }^{2}$ Associate Professor, Department of Agricultural Extension, College of Horticulture, Kerala Agricultural University, Vellanikkara-680 656, Thrissur, Kerala

Received : 17-10-2019; Accepted : 28-01-2020 
Perception on the Effectiveness of School Vegetable Garden Programme

lands in the government and private institutions under vegetable cultivation. The Vegetable and Fruit Promotion Council of Keralam (VFPCK) initiated a programme namely agri@school with its main concept 'A vegetable garden in my school'. The programme coverage is 1000 schools in the state with an aim to meet 600 tonnes of vegetable production. The programme was launched with a view to creating a curiosity, and awareness among children on the joys of being involved in agriculture. The council will provide seeds, manure, implements and technical inputs. The basic criteria for selection were that the school should have the minimum two cents and a maximum of 15 cents for a vegetable garden. Besides cultivation of vegetables, students will also be trained in waste management and vermicomposting (The Hindu, 2006). The School vegetable garden is one of the important components of government aided Vegetable Development Programme. It provides opportunities for young minds to understand the basic lessons of agriculture and develop affinity towards it. Growing crops gives a new appreciation for nature, when the learners have the opportunity to see how plants grow In order to mobilize the student community into the field of agriculture, make them aware of safe to eat products and to bring uncultivable lands in the government and private institutions under vegetable cultivation, this component provides assistance (GOK, 2012).

Major advances in technology have led to more focus being given to non- agricultural majors and careers, with less focus on knowledge of agriculture and agricultural sciences. As a result, society has become further removed from agriculture. This disconnect has resulted in failure to gain knowledge about agriculture by society as a whole (Nkembe, 2012). White (2012) stated that small-scale agriculture is the developing world's single biggest source of employment, and with the necessary support, it can offer a sustainable and productive alternative to the expansion of large-scale, capital-intensive, labor-displacing corporate farming. Even though it assumes a generation of young rural men and women who want to be small farmers, while mounting evidence suggests that young people are uninterested in farming or in rural futures. Razia (2015) reveals that with growing urbanization, better literacy standards and greater skill attainment by rural youth, our younger generation is moving away from agriculture. In India, children get hardly any exposure to agriculture through a curriculum predominated by arts and science. When young children connect with nature, we can feel that they can change the world. The garden based learning in schools is pretty much obvious then. School gardens are the best place to teach what science and nature is all about and we most certainly need them in more numbers (Basu, 2016). Keeping this in mind, a systematic study was conducted on the perception of effectiveness of school vegetable of gardens.

\section{METHODOLOGY}

Ex-post facto research design was used for the study carried out in Nenmara 
and Kollengode blocks of Palakkad district, Kerala. One school each was chosen from the three selected panchayats of each block. The six panchayats were Nenmara, Pallasana, and Elavanchery from Nenmara block and Koduvayur, Muthalamada, and Vadavannur from Kollengode. Two stage random sampling procedure was adopted. The respondents were 30 students each from the six schools in which school vegetable garden programme was implemented, which constituted 180 student respondents. The age group of students ranged from 11 to 16 years old. A standardized tool was formulated to measure the perception on the effectiveness of school vegetable garden taking into consideration the procedure adopted by Razia (2015). However the perception index was calculated using the formula -

Perception Index $=\frac{\text { Respondents total score }}{\text { Total possible score }} \times 100$

\section{FINDINGS AND DISCUSSION}

The results represented in Table 1 indicate that development of life skill is considered as the most perceived effectiveness of school vegetable garden by the students involved in school vegetable garden with 90.11 perception index and rank 1 , followed by other indicators viz., Performance of intercultural operations (85.03), Knowledge aspects (84.97), Participation and involvement of students (83.25), Improvement in environment stewardship (82.22), Selection of crop and season (71.54) and Supply of agricultural inputs (54.92).

\section{Constrains Faced by Students in Maintaining Vegetable Garden}

The constraints faced by students were identified and were asked to rate. The responses were analysed using Kendall's coefficient of concordance (w). From Table 2,

Table 1.

Distribution of Perception on the Effectiveness of School Vegetable Garden as perceived by Student Respondents

$(n=180)$

\begin{tabular}{|c|l|c|c|}
\hline SI. No. & \multicolumn{1}{|c|}{ Indicator } & Perception index & Rank \\
\hline 1. & Development of life skills & 90.11 & 1 \\
\hline 2. & Performance of intercultural operations & 85.03 & 2 \\
\hline 3. & Knowledge aspects & 84.97 & 3 \\
\hline 4. & Participation and involvement of students & 83.25 & 4 \\
\hline 5. & Improvement in environment stewardship & 82.22 & 5 \\
\hline 6. & Selection of crop and season & 71.54 & 6 \\
\hline 7. & Supply of agricultural inputs & 54.92 & 7 \\
\hline Overall Perception Index & 78.86 & \\
\hline
\end{tabular}


Table 2.

Constraints Experienced by Students

$(n=180)$

\begin{tabular}{|c|c|c|c|}
\hline \multirow{2}{*}{$\begin{array}{l}\text { Sl. } \\
\text { No. }\end{array}$} & \multirow[b]{2}{*}{ Constraints } & \multicolumn{2}{|c|}{ Students } \\
\hline & & $\begin{array}{l}\text { Mean } \\
\text { Rank }\end{array}$ & $\begin{array}{l}\text { Rank } \\
\text { order }\end{array}$ \\
\hline 1. & Inadequate irrigation facility & 8.06 & 7 \\
\hline 2. & Scarcity of land for cultivation & 8.92 & 4 \\
\hline 3. & High input cost & 8.80 & 3 \\
\hline 4. & Inadequate fund & 7.42 & 11 \\
\hline 5. & Low level of student's interest & 8.13 & 6 \\
\hline 6. & Poor knowledge about gardening & 8.47 & 7 \\
\hline 7. & Poor storage facility & 7.50 & 9 \\
\hline 8. & Less involvement of teacher's & 6.16 & 15 \\
\hline 9. & Difficulty in obtaining implements & 8.29 & 5 \\
\hline 10. & More time is spent for garden activities & 9.35 & 1 \\
\hline 11. & Crop damage by wild animals & 7.37 & 12 \\
\hline 12. & Inadequate training/ extension service & 7.89 & 10 \\
\hline 13. & Negative attitude towards physical work & 7.28 & 13 \\
\hline 14. & Theft of vegetables from school & 7.00 & 14 \\
\hline 15. & Difficulty in maintenance during vacation & 9.34 & 2 \\
\hline & Kendall's Wa & 0.06 & \\
\hline & Chi-Square & 150.681 & \\
\hline & df & 14 & \\
\hline & Asymp. Sig. & 0.000 & \\
\hline
\end{tabular}

it is evident that time spent for garden activities and difficulty in maintaining during vacation were the major constraints with respect to the students. The major constraint they experienced was 'time' because the students have to find extra time for garden activities, as there was no predefined time in the academic curriculum. There must be an initiative from the government to include an hour a day for this type of vocational learning to be included in the academic curriculum. In order to take care the crops during vacation, students coming from nearby areas, premises need to get allotted the gardening duties. The input cost can be substantially reduced by making use of the available natural and organic sources like botanical and manual means. The availability of implements can 
either be improved by means of raising funds and purchasing implements through this garden clubs or by hiring from custom hiring centres. It was also noted that the constraints such as lack of teacher's involvement, theft of vegetables from the school during vacation and negative attitude towards physical work were of least importance. It implies that the teachers were actively directing the students in all the garden activities and the members in the garden clubs were not hesitant in doing physical work.

This result is similar to the the study report of Dilip and Thomas (2017). High input cost, lack of student's participation, lack of teacher's involvement, non-availability of implements, high labour cost, poor storage facilities and lack of knowledge about gardening were the major issues in managing a school vegetable garden.

\section{CONCLUSION}

Encouraging and equipping the children to do simple agricultural activities will offer physiological, psychological, recreational and cognitive benefits. Analysing the various phases of crop production right from seed germination, taking care of small plants and different intercultural operations up to harvesting the final produce will itself help to develop enthusiasm among children. Projects which encourage garden component in educational institutions and a teacher specially recruited to provide guidance and training in these aspects are vital for the emerging generation, as the results reveal.

\section{REFERENCES}

Basu, S. (2016). Learning by doing. The Hindu, 27 Jan., 2016.

Dilip, S. \& Thomas, A. (2017). Constraints perceived by students in school vegetable gardening, Journal of Extension Education. 29(1):5818-5822.

GOK [Government of Kerala]. (2012). Vegetable Development Programme 201213 Circular, 48p.

Nkembe, E.N. (2012). Agriculture: what do children really know? Unpubished MSc (Ag) thesis, University of Georgia, Athens,81p.

Razia, F. (2015). Perception of school students of Kerala on agriculture and its implications. Unpublished MSc (Ag) thesis, Kerala Agricultural University, Thrissur, 188p.

The Hindu. (2006). 40 schools chosen for Agri at school programme. The Hindu, 4 July,2006.

White,B.(2012).Agricultureand thegeneration problem: rural youth, employment and the future of farming In:Sumberg J, Wellard $\mathrm{K}$ (Eds), Young people and agriculture in Africa. IDS Bulletin, pp 9-19. 